\title{
OESTRUS, OVULATION AND FERTILITY FOLLOWING SUPPRESSION OF OVARIAN CYCLES IN MERINO EWES BY PROGESTERONE
}

\author{
D. R. LAMOND AND B. M. BINDON \\ C.S.I.R.O. Division of Animal Physiology, Pastoral Research Laboratory, Armidale, and \\ Faculty of Rural Science, University of New England, Armidale, N.S.W., Australia
}

(Received 3rd November 1961)

Summary. Progesterone was administered to Merino ewes in February (early breeding season) and May (mid-breeding season) for 2 weeks. The period from the final progesterone injection to the onset of oestrus, the duration of oestrus, and fertility after hand mating were observed. The approximate time of ovulation was also determined in the February experiment.

The duration of oestrus was 10 to $50 \mathrm{hr}$; ovulation took place near the end of oestrus. The period from the last injection to the onset of oestrus, and the fertility of the ewes were influenced by dose, interval between consecutive progesterone injections, the time of day that the injections were given, and the stage of the breeding season. Variability in onset of oestrus (indicating the degree of synchronization of oestrus) was least when the final injections were given in the morning.

The results clearly show that normal levels of fertility may be achieved after synchronization of oestrus in Merino ewes with progesterone.

\section{INTRODUCTION}

Lamond \& Lambourne (1961) demonstrated that the onset of oestrus following suppression of ovarian cycles with progesterone was dependent on the dose of progesterone, and the interval between injections. Fertility from natural service was variable; the factors causing the variation were not obvious. Fertility has been variable, though generally low in numerous other studies in which ewes (Dutt \& Casida, 1948; O'Mary, Pope \& Casida, 1950; Hunter, 1954; Robinson, 1956, 1960), cows (Willett, 1950; Ulberg, Christian \& Casida, 1951; Trimberger \& Hansel, 1955; Nellor \& Cole, 1956; Ulberg \& Lindley, 1960), and sows (Baker, Ulberg, Grummer \& Casida, 1954) have been inseminated at the first heat after progesterone suppression of oestrous cycles. It is conceivable, however, that there might be an optimum doseinterval relationship for progesterone which will give a high degree of synchronization accompanied by high fertility.

This paper describes further studies in which satisfactory fertility has been obtained to natural service following cessation of progesterone injections to cycling Merino ewes. 


\section{MATERIALS AND METHODS}

ANIMALS

Adult Merino ewes with a satisfactory breeding history were yarded a few days before commencement of progesterone injections. They were fed a grainchaff maintenance ration. The ewes were randomly allotted to treatment groups but were run together so that those receiving injections at 2-day intervals were run through the race where injections were carried out at the same time as ewes receiving daily injections. On the day before the first oestrus was expected, all ewes were placed in small uncovered yards, six to eight ewes per yard.

In Experiment 1, the approximate time of ovulation was determined by exploratory laparotomy a few hours after cessation of oestrus. The methods of laparotomy and estimation of time of ovulation are described elsewhere (Lamond \& Urquhart, 1961; Lamond, 1962). On completion of each experiment, the ewes were returned to pasture. Pregnancy diagnosis was carried out 2 months later, using the laparotomy method described by Lamond \& Urquhart (1961).

\section{Experiment 1}

\section{EXPERIMENTAL DESIGNS}

Fifty-six ewes were randomized into eight groups of seven each and injected daily or at intervals of 2 days (2-daily) with progesterone. The progesterone was dissolved in arachis oil, $10 \mathrm{mg}$ per $\mathrm{ml}$, and was injected intramuscularly. Injections continued for 13 days and were given at 9 to 9.30 a.m. each day. On the 13th day (= Day 0 - day of final injection) the hormone was given either at 6 a.m. or 4 p.m. The experimental design was a $2^{2} \times 2$ factorial, as follows:

(a) Total dose of progesterone: $10 \mathrm{mg}$ per day, $20 \mathrm{mg}$ per day.

(b) Interval between injections: $24 \mathrm{hr}, 48 \mathrm{hr}$. Hence the progesterone treatments were: $10 \mathrm{mg}$ per day, $20 \mathrm{mg}$ every 2 days, $20 \mathrm{mg}$ per day, $40 \mathrm{mg}$ every 2 days.

(c) Time of final injection: 6 a.m., 4 p.m.

Two vasectomized raddled rams were put with the group on the day of the first progesterone injection. Examination for onset of oestrus using entire rams began on the 2nd day after the final injection of progesterone (Day 2).

Injections commenced on 6th February 1961, and Day 0 was 18th February.

\section{Experiment 2}

Fifty-six ewes were randomized into eight groups and injected with progesterone daily or every 2 nd day for 13 days. Injections were given at 8 a.m. or 4 p.m. each day and on the final day half the ewes which had been receiving progesterone in the afternoon were injected in the morning and vice versa. The design was therefore a $2 \times 2^{2}$ factorial, as follows:

(a) Progesterone: $20 \mathrm{mg}$ per day, $20 \mathrm{mg}$ per 2 days.

(b) Suppressive doses of progesterone given: 8 a.m., 4 p.m.

(c) Final dose of progesterone given: 8 a.m., 4 p.m.

Vasectomized rams were not joined with these ewes. The first checks for 
oestrus took place on the evening of Day 2. These ewes were not examined for time of ovulation.

The experiment commenced on 19th April 1961, and Day 0 was 1st May 1961. Two ewes were eliminated from the results of this experiment because they failed to come into oestrus.

\section{DETECTION OF OESTRUS}

Twelve entire Merino rams were used for detection of oestrus. Every 4 to $6 \mathrm{hr}$ (the shorter period during the daylight hours) pairs of rams were put in pens with six to eight ewes. Ewes which were in oestrus were removed from the pen; when the rams ceased working, fresh ones were introduced for a final check. There were marked differences in libido between rams; some inspected every ewe thoroughly and others seemed only to tease ewes that were on heat. In the periods between oestrus checks, the rams were run in a yard near the ewes. Ewes which stood and allowed a ram to mount were judged to be in oestrus.

The time midway between a negative and a positive check was taken as the time of onset of oestrus. The time midway between the last positive check and the first negative one was taken as the end of oestrus. Ewes which showed two successive negative checks after oestrus were not examined further. Cessation of oestrus was abrupt in all ewes except one which gave one negative check followed by a positive one. The onset was more variable, although a large proportion of ewes did not show oestrus at one check and were on heat at the next. In the remainder the ewes attracted the ram at one examination and were fully on heat at the next.

\section{RESULTS}

PERIOD FROM PROGESTERONE TO THE ONSET OF OESTRUS

The means of the periods (in hours) from the time of the final injection of progesterone to the onset of oestrus are presented in Table 1 and Text-fig. 1. Whereas the within-group variances were homogeneous in May, significant differences were present in the February results $\left(\chi_{(7)^{2}}=17.56,0.01<P<0.02\right)$. The square root transformation was found to reduce heterogeneity but not to eliminate it entirely $\left(\chi_{(7)^{2}}{ }^{2}=14.48,0.02<P<0.05\right)$. Nevertheless, the transformed data were submitted to an overall analysis of variance, summarized in Table 2. The heterogeneity in variances was due to greater variability following afternoon injections. The original data were therefore also submitted to two separate analyses (Table 2).

In February, there was a significant effect both of total dose of progesterone and of intervals between injections. After the final injection in the morning, the period to onset of oestrus in the 20 -mg-daily ewes was $24 \mathrm{hr}$ longer than in 10 -mg-daily ewes; $20 \mathrm{mg}$ every 2 days was intermediate while $40 \mathrm{mg}$ every 2 days resulted in mean onset of oestrus $12 \mathrm{hr}$ later than $20 \mathrm{mg}$ per day (Textfig. 1). Comparisons between morning and afternoon results showed that daily treated ewes, receiving the final injection of progesterone in the afternoon, commenced oestrus earlier than similar ewes injected in the morning. In the 


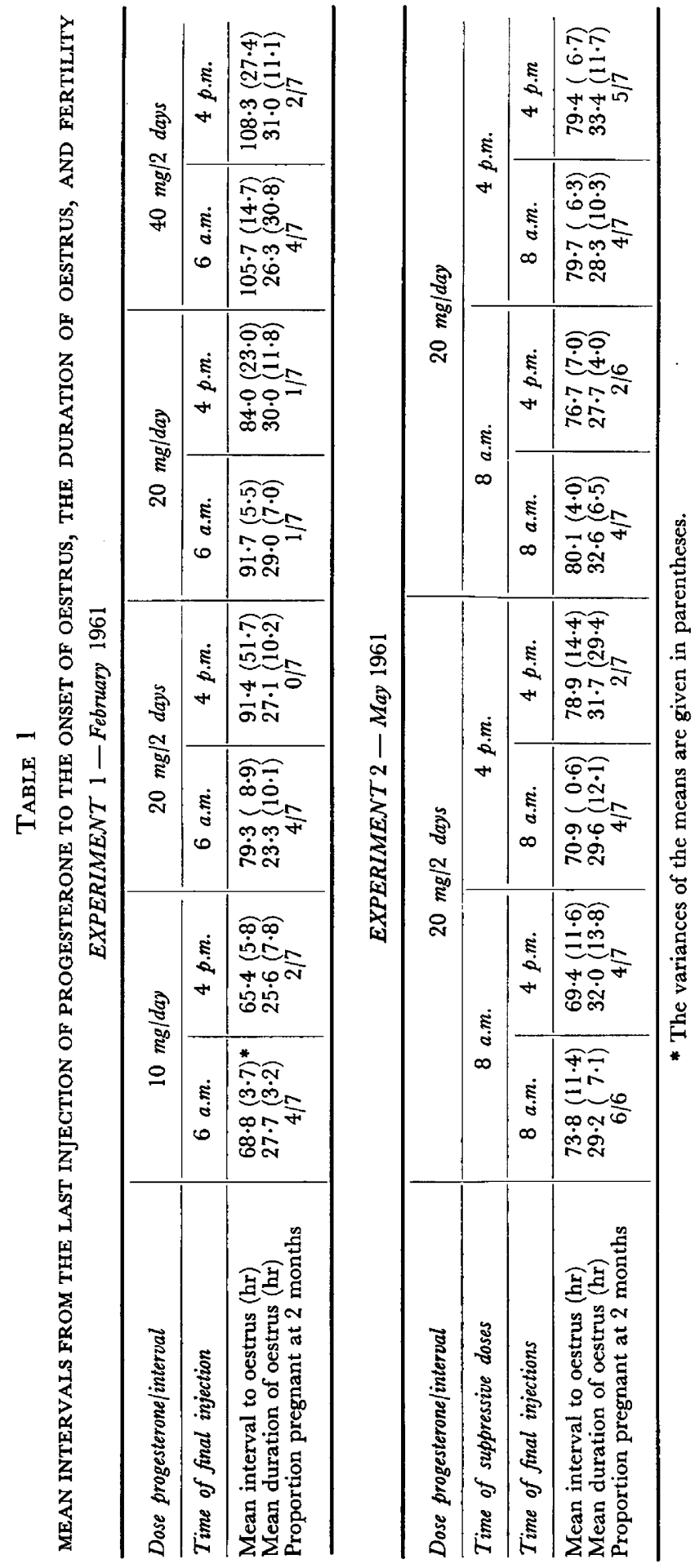


Fertility after progesterone in ewes

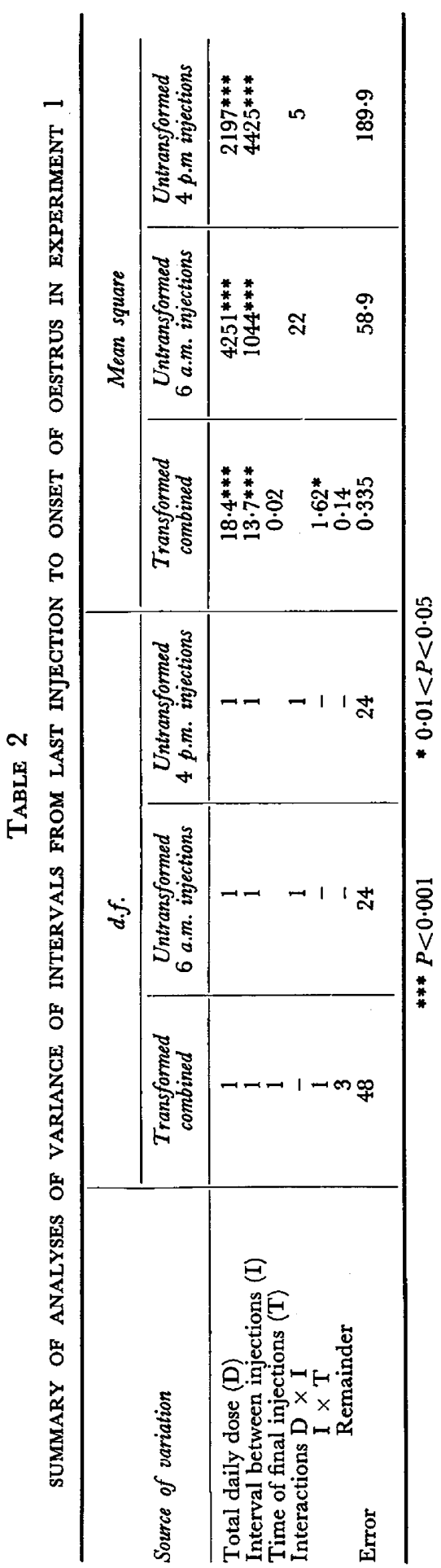


2-daily groups, the opposite trend was apparent. In the May experiment, differences in the time of day when the suppressive doses of progesterone were administered and in the time of day final injections were given, did not result in significant differences in the period to oestrus.

Comparisons of the results of 20-mg-per-day and 20-mg-per-2-days treatments at the two times of the year are seen in Text-fig. 1. The following points may be noted:

(i) The period to onset of oestrus after $20 \mathrm{mg}$ daily (morning injections), was approximately $12 \mathrm{hr}$ shorter in May, giving a result such as would have been expected with approximately $13 \mathrm{mg}$ of progesterone per day in February.

(ii) In February, following the morning injections, oestrus was $12 \mathrm{hr}$ earlier after $20 \mathrm{mg}$ per 2 days than following $20 \mathrm{mg}$ per day. In May the difference was $6 \mathrm{hr}$.

(iii) The mean time of onset of oestrus after $20 \mathrm{mg}$ per 2 days given in the

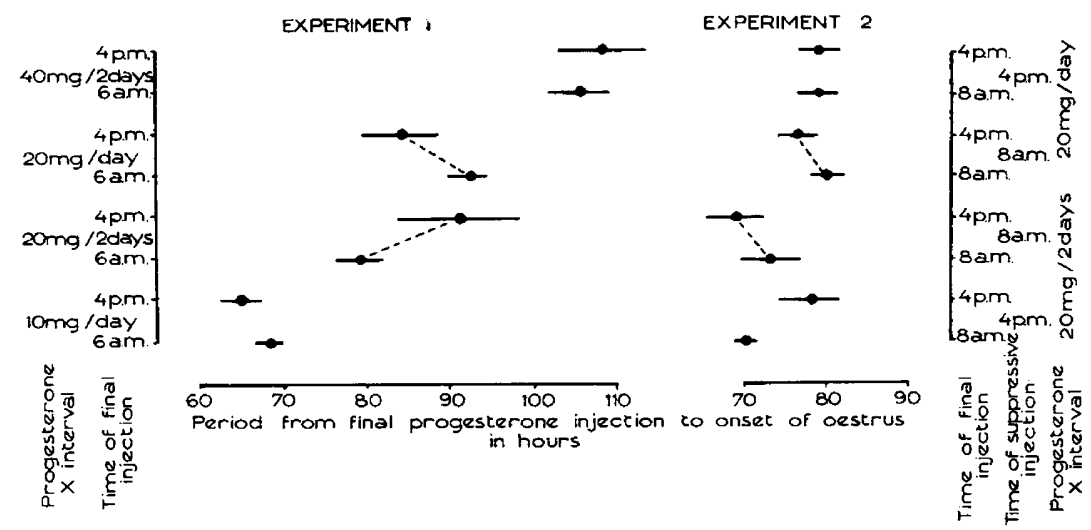

TexT-Fig. 1. Diagrammatic representation of the mean periods from the final injection of progesterone to onset of oestrus in Experiments 1 and 2. The standard errors of the means are also shown.

afternoon was nearly $24 \mathrm{hr}$ earlier in May than in February and the variance was approximately one-fifth.

There was no significant correlation within any of the dosage groups in either February or May, between the intervals from penultimate to final injection and the onset of oestrus after the final injection.

\section{DURATION OF OESTRUS}

The mean duration of oestrus in each experiment is presented in Table 1 and shown graphically in Text-fig. 2 (Experiment 1 only). There were no differences between treatments in February or May; the average length of oestrus was approximately $3 \mathrm{hr}$ greater in May, but the difference, however, was not statistically significant. The length of oestrus is thought to reach a maximum in the middle of the breeding season (McKenzie \& Terrill, 1937) and the present trend is thus similar. Variation in duration of oestrus was considerable, ranging from 10 to $50 \mathrm{hr}$. 
TIME OF OVULATION

The approximate times of ovulation are shown in Text-fig. 2. Data for Experiment 1 only are available. Ovulation occurred near the end of oestrus which is the usual time in normal cycling ewes (McKenzie \& Terrill, 1937).

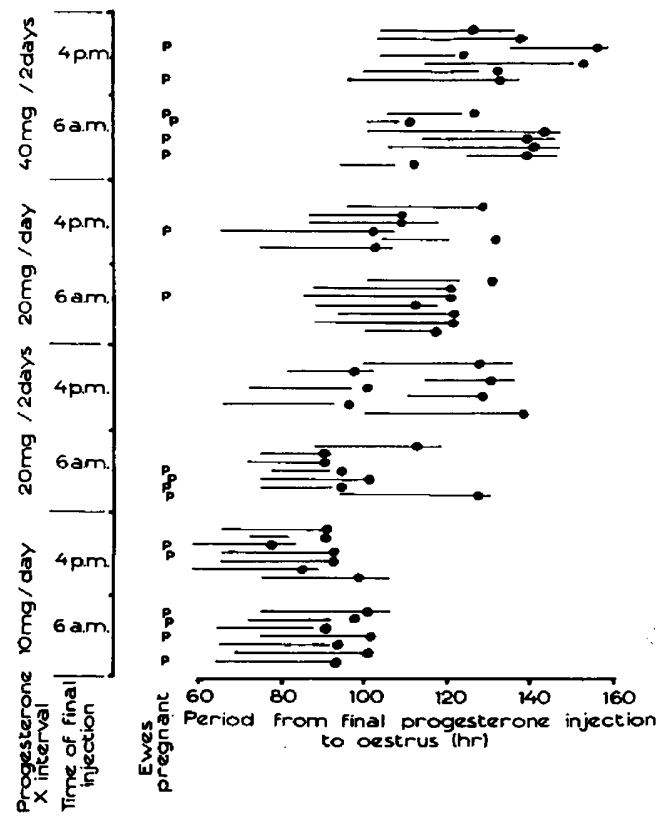

Text-Fig. 2. Diagrammatic representation of the onset and length of oestrus in relation to the final injection of progesterone in Experiment 1 . The ewes that conceived to service during the heat period are indicated in the diagram by the letter $P$.

$\rightarrow$ represents the approximate time of ovalation.

\section{FERTILITY}

The number of ewes pregnant at 2 months in each experiment is shown in Table 1. Summaries of the analyses of variance are presented in Tables 3 and 4.

TABLE 3

SUMMARY OF ANALYSIS OF VARIANCE OF FERTILITY RESULTS IN EXPERIMENT 1

\begin{tabular}{l|c|c|c}
\hline \multicolumn{1}{c|}{ Source of variation } & d.f. & Mean square & $F$ \\
\hline Total daily dose (D) & 1 & $2 \cdot 8$ & \\
Interval between injections (I) & 1 & $2 \cdot 8$ & \\
Time of final injection & 1 & $854 \cdot 9$ & $7 \cdot 28^{* *}$ \\
Interaction D $\times$ I & 1 & $600 \cdot 3$ & $5 \cdot 12^{*}$ \\
Remainder & 3 & $210 \cdot 8$ & \\
Error variance & $\infty$ & $117 \cdot 2$ & \\
\hline \multicolumn{2}{c|}{ Transformed to angles, $\mathrm{n}=7}$. \\
$* 00001<P<0.01$
\end{tabular}

Overall fertility was much higher in May: in comparable treatments the number of pregnancies was nearly doubled when compared with February. 
In general, the depression of fertility in ewes receiving their final injection in the afternoon was significant in February $(P<0.01)$ and barely significant in May $(P \bumpeq 0.05)$. In February, also, $20 \mathrm{mg}$ per day gave significantly lower fertility than $10 \mathrm{mg}$ per day, thus indicating an effect on fertility due to dosage level of progesterone.

TABLE 4

SUMMARY OF ANALYSIS OF VARIANCE OF FERTILITY RESULTS IN EXPERIMENT 2

\begin{tabular}{l|c|c|c}
\hline \multicolumn{1}{c|}{ Source of variation } & d.f. & Mean square & $F$ \\
\hline Interval between injections (I) & 1 & $107 \cdot 3$ & \\
Time of suppressive doses (S) & 1 & $4 \cdot 5$ & \\
Time of final injection & 1 & $494 \cdot 6$ & $4 \cdot 22$ \\
Interaction I X S & 1 & $802 \cdot 0$ & $6 \cdot 84^{*}$ \\
Remainder & 3 & $205 \cdot 1$ & \\
Error variance & $\infty$ & $117 \cdot 2$ & \\
\hline \multicolumn{2}{c}{ Transformed to angles, $\mathrm{n}=7}$. \\
\end{tabular}

In Experiment 1, the correlation between fertility and length of oestrus was not significant. The approximate time of day when ovulation took place and the corresponding fertility are presented in Table 5 . There were significantly more ovulations during some 3 -hr periods than others, notably prior to midday and midnight $\left(\chi_{(7)}{ }^{2}=23.0 ; 0.001<P<0.01\right)$. There did not seem any

TABLE 5

RELATIONSHIP BETWEEN TIME OF OVULATION AND FERTILITY

\begin{tabular}{l|c|c|c|c}
\hline \multicolumn{1}{c|}{$\begin{array}{c}\text { Nestimated time of } \\
\text { ovulation }\end{array}$} & \multicolumn{3}{|c|}{ No. ezes } & \\
\cline { 2 - 5 } & Pregnant & Non-pregnant & Totals & $\begin{array}{c}\text { Pregnant } \\
(\%)\end{array}$ \\
\hline 3 a.m. to 6 a.m. & 3 & 5 & 8 & 37 \\
6 a.m. to 9 a.m. & 2 & 4 & 6 & 33 \\
9 a.m. to noon & 5 & 5 & 10 & 50 \\
Noon to 3 p.m. & 1 & 1 & 2 & 50 \\
3 p.m. to 6 p.m. & 0 & 4 & 4 & 0 \\
6 p.m. to 9 p.m. & 1 & 2 & 3 & 33 \\
9 p.m. to midnight & 6 & 11 & 17 & 30 \\
Midnight to 3 a.m. & 0 & 6 & 6 & 0 \\
\hline
\end{tabular}

particular time of the day when fertility was better than other times $\left(\mathrm{X}_{(7)^{2}}=\right.$ $5 \cdot 77 ; 0.5<P<0 \cdot 7)$.

\section{DISGUSSION}

It is evident from the results that the doses of progesterone employed were effective in suppressing ovarian activity and that in certain treatments synchronization of oestrus and fertility were satisfactory after cessation of these injections. Thus we have obtained confirmation of the general hypothesis investigated in these studies - that it is possible to devise methods for using 
progesterone that will give a high degree of synchronization accompanied by a reasonable level of fertility. There are evidently a number of optimal methods and the doses employed may be termed optimal suppressive doses (OSD). Factors influencing the OSD in this experiment were interval between injections, time of day of final injection and stage of breeding season.

It is important to consider the relationship between the osD for any particular method of administration and the minimal suppressive dose (MSD), which is the minimum amount needed to suppress ovarian activity, for that method of administration. Both in this experiment and in that of Lamond \& Lambourne (1961), the evidence suggests that the OsD is greater than the MSD, but that the magnitude differs with different régimes. Further work should establish the exact nature of the relationship which is of importance in elucidating the mode of action of progesterone, particularly as to whether the more important effect of progesterone is its action on the genital tract or its action on the hypothalamicpituitary system.

There is some evidence from the present results that after cessation of different progesterone treatments the activity of the hypothalamic-pituitary system followed a normal pattern. Thus the length of oestrus was normal and the occurrence of ovulation in relation to oestrus was also apparently normal. After cessation of OSD injections, the period to oestrus and ovulation probably coincides with changes in the genital tract consistent with normal fertilization, transport and nidation. With doses other than the OSD, the time relationship possibly does not hold.

The onset of oestrus in Experiment 1 after the 6 a.m. injections and the change in pattern in May provide information on progesterone action. In February, oestrus began at an average time of $69 \mathrm{hr}$ after $10 \mathrm{mg}$ per day and $92 \mathrm{hr}$ after $20 \mathrm{mg}$ per day. The interval after $20 \mathrm{mg}$ every 2 days was intermediate, and $40 \mathrm{mg}$ per 2 days was $12 \mathrm{hr}$ later than $20 \mathrm{mg}$ per day. Compared to February, oestrus in May was $6 \mathrm{hr}$ earlier after $20 \mathrm{mg}$ per 2 days and $12 \mathrm{hr}$ earlier after $20 \mathrm{mg}$ per day. These results show that the onset of oestrus can be influenced by dose, by intervals between doses, and by the time of year. This raises the question of whether the differences in onset of oestrus are due to treatment differences in ovarian follicular development at the time of the final injection, or whether some form of central inhibition takes place, leading to differences between treatments in the rate at which the hypothalamic-pituitary system recovers, or perhaps a combination of both.

Seasonal differences in OSD may be interpreted to mean that the processes that progesterone suppresses are better established and more highly organized near the middle of the breeding season than at the beginning. Quantitative studies of seasonal changes in MSD (which is more readily measured) are at present under investigation.

\section{ACKNOWLEDGMENTS}

The authors are indebted to Dr G. R. Moule and Dr A. W. H. Braden of the C.S.I.R.O. Division of Animal Physiology, for valuable criticism and comments. 


\section{REFERENCES}

Baker, L. N., Ulberg, L. G., Grummer, R. H. \& CAsida, L. E. (1954) Inhibition of heat by progesterone and its effect on subsequent fertility in gilts. F. Anim. Sci. 13, 648.

DutT, R. H. \& CASIDA, L. E. (1948) Alteration of the estrual cycle in sheep by use of progesterone and its effect upon subsequent ovulation and fertility. Endocrinology, 43, 208.

HUNTER, G. L. (1954) Attempts to synchronize the occurrence of oestrus in sheep as a preliminary to ovum transplantation. F. Endocrin. 10, xiii.

LAMOND, D. R. (1962) Effect of season on hormonally induced ovulation in Merino ewes. F. Reprod. Fertil. 4, 111.

Lamond, D. R. \& Lambourne, L. J. (1961) Suppression of oestrus in sheep with progesterone. Aust. F. agric. Res. 12, 154.

LAmond, D. R. \& URQuhart, E. J. (1961) Sheep laparotomy cradle. Aust. Vet. F. 37, 430.

McKenzIE, F. F. \& Terrill, C. E. (1937) Oestrus, ovulation and related phenomena in the ewe. Univ. Mo. agr. exp. Sta. res. Bull. p. 264.

Nellor, J. E. \& Cole, H. H. (1956) Hormonal control of estrus and ovulation in the beef heifer. $\mathcal{F}$. Anim. Sci. 15, 650.

O'Mary, C. C., Pope, A. L. \& Casida, L. E. (1950) The use of progesterone in the synchronization of the estrual periods in a group of ewes and the effect on their subsequent lambing records. 7. Anim. Sci. 9, 449.

Robinson, T. J. (1956) The artificial insemination of the Merino sheep following synchronization of oestrus and ovulation by progesterone injected alone and with pregnant mare serum gonadotrophin (PMs). Aust. F. agric. Res. 7, 194.

Robinson, T. J. (1960) Advances in controlled sheep breeding. Proc. N.Z. Soc. Anim. Prod. p. 42.

Trimberger, G. W. \& Hansel, W. (1955) Conception rate and ovarian function following estrus control by progesterone injections in cattle. F. Anim. Sci. 14, 224.

Ulberg, L. G., Christlan, R. E. \& Casma, L. E. (1951) Ovarian response in heifers to progesterone injections. F. Anim. Sci. 10, 754 .

UlBERG, L. C. \& LindLey, G. E. (1960) Use of progesterone and estrogen in the control of reproductive activities in beef cattle. $\mathcal{F}$. Anim. Sci. 19, 1132.

Willett, E. L. (1950) The fertility of heifers following administration of progesterone to alter the estrual cycle. F. Dairy Sci. 33, 381. 